\title{
A liberdade de expressão na jurisprudência do STF (2017-2020): justificativa poliárquica e o teste da posição preferencial relativa
}

\author{
Freedom of expression in the jurisprudence of supreme court (2017-2020): polyarchic \\ justification and the relative preferential position test
}

Breno Baía Magalhães*

\section{Resumo}

O estudo analisou a produção jurisprudencial do Supremo Tribunal Federal nos anos de 2017 a 2020, a fim de investigara existência de alguma justificativa desenvolvida pela Corte para explicara posição política do direito à liberdade de expressão no Brasil e, se for o caso, quais testes são empregados para a solução de controvérsias surgidas entre esse direito e outros valores constitucionais. A pesquisa concluiu que, dentre as justificativas possíveis para explicar a liberdade de expressão, a Suprema Corte deu preferência a uma leitura instrumental do direito fundamental de recorte democrático, cuja função seria garantir participação em um espaço livre de interferência estatal para que o cidadão expresse sua oposição política. O conteúdo dessa manifestação, ademais disso, reflete tradicionais interpretações sobre a formação do estado e sociedade brasileiros. Os ministros empregaram a proporcionalidade e a posição preferencial como testes para solucionar conflitos entre o direito à livre manifestação e outros direitos. Entretanto, não foi possível distinguir a força operativa dos testes na prática da Corte, em razão da confusão conceitual característica propagada em seus votos.

Palavras-chave: Liberdade de Expressão. Supremo Tribunal Federal. Poliarquia. Posição Preferencial. Proporcionalidade.

\section{Abstract}

The study analyzed the STF's case law in the years 2017 to 2020, in order to delimit if there is any justification developed by the Court to explain the political position of the right to freedom of speech in Brazil and, if applicable, which tests are used for the resolution of controversies that arose between this right and other constitutional values. The research concluded that, among the possible justifications to explain freedom of speech, the Supreme Court gave preference to an instrumental reading of the constitutional right of a democratic nature, whose function would be to guarantee a space free of state interference so that the citizen may express his political opposition. The content of this manifestation, moreover, reflects traditional interpretations about the formation of the Brazilian state and society. Justices employed proportionality and preferential position as tests to solve conflicts between the right to free speech and other rights. However, it was not possible to distinguish the operative strength of the tests in the practice of the Court, due to the conceptual confusion characteristic of his votes.

Keywords: Freedom of expression. Federal Court of Justice. Polyarchy. Preferred Position. Proportionality.

\section{Introdução}

Direitos fundamentais são manifestações institucionalizadas de um conjunto de interesses políticos resguardados por regras jurídicas dotadas de superioridade normativa, as quais, como consequência de sua violação, habilitam seus titulares a mobilizar os aparelhos coercitivos estatais para fazer cessar os atos do poder público que os atinjam ${ }^{1}$. A linguagem empregada pela Constituição brasileira para positivar essa categoria de direitos é, por vezes, abstrata, além de oferecer poucos indicativos sobre como solucionar conflitos entre interesses políticos relevantes garantidos constitucionalmente, sejam eles particulares ou públicos (VIEIRA, 2017, p. 40).

(9) (iD Doutor e mestre em Direito pela Universidade Federal do Pará (UFPA). Professor de Direito Constitucional da Universidade Federal do Pará (UFPA). Pesquisador visitante na Universidade Nacional de Lanús (2018). Menção honrosa no prêmio CAPES de teses (2016). Foi Visiting Scholar na Washington College of Law, American University (2015). E-mail: brenobaiamag@gmail.com

A formulação apresentada adota pressupostos passíveis de contestação por alguns teóricos, a exemplo da pressuposição de que direitos fundamentais são interesses ou de que devem estar previstos em normas constitucionais. A observação está correta, mas justifica-se o emprego dessa formulação como base descritiva do modelo de constitucionalização brasileiro. Para maiores detalhes acerca das diversas teorias sobre direitos da cf., checar os textos que compõem a coletânea organizada por Waldron (1984). 
O parágrafo acima, sinteticamente, demonstra a íntima relação existente entre direito e a filosofia política, moral e da linguagem (MARMOR, 2011). O exercício da jurisdição constitucional não escapa dos problemas decorrentes dessa interação, uma vez que os ministros de nossa Suprema Corte precisam decidir temas sensíveis de moralidade política a partir de fragmentos de textos abstratos e vagos. Essa é uma das razões pelas quais a tarefa de fazer previsões seguras a respeito do resultado de um caso controverso que envolva direitos fundamentais é, virtualmente, impossível.

Há, no entanto, duas formas por meio das quais o fenômeno jurídico pode auxiliar o exercício da hermenêutica constitucional $^{2}$. Uma primeira, de ordem prática, está na fixação de parâmetro normativos de menor grau de abstração para a solução de casos concretos. Esses padrões normativos menos abstratos, por vezes empregados pelas cortes, podem assumir várias formas e, longe de serem capazes de seguramente antecipar resultados, fornecem ferramentas à audiência da Corte para que possa compreender seu raciocínio jurídico. Jurisprudencialmente, uma corte pode fixar teses, elaborar testes, doutrinas ou desenvolver teorias aplicáveis ${ }^{3}$ quando determinada espécie de conflito constitucional requerer uma solução específica.

Por outro lado, uma das funções desempenhadas pela dogmática jurídica é fornecer substratos teóricos às cortes, a partir da racionalização de seus próprios precedentes e da produção científica correspondente, a fim de conferir ao direito constitucional coerência e sistematização (RODRIGUEZ, 2012, p. 21-32). No campo dos direitos fundamentais, a produção dogmática contribui significativamente para a formulação de justificativas ou teorias explicativas sobre os interesses políticos constitucionalizados dentro da sistemática mais ampla da estrutura política comunitária. Ou seja, e para ilustrar com o direito objeto de análise deste trabalho, a dogmática pode ser útil no processo de decisão constitucional ao fornecer ao juiz explicações a respeito do papel desempenhado pela proteção do interesse político de expressar-se livremente no sistema constitucional brasileiro. Em síntese, as explicações doutrinárias sobre o porquê dos brasileiros serem titulares desse direito fundamental de liberdade que auxiliam a Suprema Corte na estipulação de seu conteúdo e eventuais limites.

Para facilitar a compreensão de ambos os critérios, reduzir-se-á a contribuição dogmática à formulação de justificativas para o exercício da liberdade de expressão e a fixação de padrões normativos jurisprudenciais, como testes para a solução de conflitos entre interesses constitucionais. A partir desta delimitação, o estudo analisará a produção jurisprudencial do Supremo Tribunal Federal (STF) nos anos de 2017 a 2020, período de estabilização na composição da Corte. A investigação pretende delimitar se existe alguma justificativa desenvolvida pela Corte para embasar a interpretação do direito à liberdade de expressão no Brasil e, se for o caso, quais testes são empregados pelo tribunal para a solução de controvérsias sobre esse direito e outros valores constitucionais.

A pesquisa concluiu que, dentre as justificativas existentes para explicar a liberdade de expressão, o STF deu preferência a uma leitura instrumental do direito fundamental de recorte democrático, cuja função seria garantir a participação em um espaço livre de interferência estatal para que o cidadão expresse sua oposição política. O conteúdo dessa manifestação, ademais disso, reflete tradicionais interpretações sobre a formação do estado e sociedade brasileiros. Os ministros empregaram a proporcionalidade e a posição preferencial como testes para solucionar conflitos entre o direito à livre manifestação e outros direitos. Entretanto, não foi possível distinguir a força operativa dos testes na prática da Corte, em razão da confusão conceitual, característica propagada nos votos dos ministros.

A formulação de padrões jurisprudenciais normativos e de justificativas teóricas de baixo grau de abstração não será trabalhada neste artigo como tábuas de salvação dos conflitos interpretativos sobre direitos fundamentais. A sugestão feita é a de que sejam capazes de oferecer uma modesta racionalização jurídica em sua vertente jurisprudencial e científica. Reconhecemos que a sugestão, não obstante modesta, encontraria adversários em ambos os campos.

3 Ao tratar das normas de direitos fundamentais, Oscar Vieira sugere que a postura institucional do STF depende da fixação de standards (padrões) racionais. Formulados em diálogo com a academia, esses padrões serviriam para que a sociedade estabilize suas expectativas em relação ao comportamento judicial e para que possa exercer maior controle de sua atuação. Por fim, em análise muito otimista, afirma que o STF tem "se mostrado apenas parcialmente capaz de estabelecer padrões claros e consistentemente aplicados em sua jurisprudência de direitos fundamentais" (VIEIRA, 2017, p. 47). Não obstante tenha feito um pequeno inventário para explicar a alteração substantiva trazida pela Corte Constitucional alemã a respeito da função desempenhada pelos direitos fundamentais na república, os quais se afastaram de posições individuais negativas, para assumir o posto de princípios valorativos de uma ordem total, Habermas exemplificou que aquela Corte tem lançado mão de um complexo léxico conceitual de ideias-chave para tomar suas decisões, entre as quais, o autor menciona o 1) efeito recíproco; 2) conteúdo essencial; 2) limites implícitos aos direitos básicos; 3) o efeito radiante e o 4) caráter objetivo dos direitos fundamentais. (HABERMAS, 1998, p. 247-248). A Suprema Corte dos Estados Unidos da América (EUA), por exemplo, criou o teste do escrutínio judicial estrito. De acordo com esse padrão, as leis que tratam de temas sensíveis ou que restrinjam direitos irão sobreviver ao escrutínio judicial apenas se "necessárias" ou "criadas adequadamente" (narrowly tailored) para promover um "interesse governamental forte" (compelling government interest) (FALLON JR, 2019). 


\section{As justificativas doutrinárias para o exercício da livre manifestação do pensamento e sua prática jurisprudencial: democracia poliárquica e formação estatal tradicional}

No campo das justificativas dogmáticas, é possível identificar, ao menos, três possíveis explicações para o exercício da liberdade de expressão no ordenamento constitucional brasileiro: 1) fortalecimento da democracia; 2) livre mercado de ideias/descoberta da verdade; e 3) desenvolvimento de interesses pessoais (CARBONELL, 2011, p. 88). A partir da formulação feita pela dogmática constitucional nacional, os principais argumentos das justificativas acima elencadas serão sumarizados.

Fortalecimento da democracia: de acordo com esta justificativa, as pessoas são livres para manifestar seu pensamento, mas o interesse protegido pelo direito fundamental alcança apenas o conteúdo da expressão que, de alguma forma, ofereça algo de importante para o governo democrático - desde a crítica aos governantes, até o desenvolvimento de discursos provocativos sobre temas relevantes para a comunidade política (LAURENTISS; THOMAZINI, 2020). Dentro desta perspectiva, há uma maior proteção do discurso político, ao mesmo tempo em que há a desconfiança de temas alheios a essa pauta, os quais estarão submetidos a um controle mais rigoroso de seu conteúdo. A avaliação instrumental sobre a proteção jurídica do discurso depende de sua propensão em garantir ou promover ideais democráticos.

Livre mercado de ideias/descoberta da verdade: a justificativa para garantir a livre expressão é fornecer um ambiente de debates livres, a operar sob a lógica de mercado para que, eventualmente, a verdade ou a melhor resposta emerjam. O mercado de ideias, dessa forma, é quem determinaria a extensão da proteção jurídica do discurso - independentemente de seu valor intrínseco, as regras do mercado definirão a força do argumento sagrado vencedor da competição entre ideias (SANKIEVICZ, 2011, p. 26). Ou seja, não necessariamente o discurso juridicamente protegido disporá de valor democrático intrínseco.

Desenvolvimento de interesses pessoais: por vezes trabalhado sob a rubrica de "intrínseca", essa justificativa para o exercício da liberdade de expressão desassocia esse direito do cumprimento de qualquer tipo de função, seja a melhoria da democracia, a descoberta da verdade ou a vitória numa disputa mercadológica de ideias. Pensado como um direito moral dos cidadãos de dizer e ouvir o que querem - algo intimamente ligado à sua dignidade - a livre expressão encontraria seu fundamento e limite no desenvolvimento da personalidade individual (KOATZ, 2011, p. 394).

Essas foram as justificativas que a dogmática nacional tomou de empréstimo dos debates gestados nos EUA sobre o direito encartado na primeira emenda à constituição daquele país. Atitude intelectualmente compreensível, até certo ponto, em razão do elevado grau de desenvolvimento teórico e maturidade jurisprudencial experimentadas pelos Estados Unidos ao longo de mais de duzentos anos de democracia liberal.

A postura da academia jurídica brasileira, a qual como poucos campos da ciência representam com galhardia certa tradição do pensamento intelectual nacional ${ }^{4}$, pode ser criticada pela incorporação impensada de um modelo teórico que pode não explicar a prática local com exatidão. Sem a intenção de aprofundar-se no debate metodológico sobre a aplicação de teorias explicativas de fenômenos jurídicos, formular-se-á, nos parágrafos seguintes, um modelo ideal representativo do processo de construção teórico/conceitual dos autores constitucionais com o fim de realçar os possíveis reveses desta postura acadêmica.

Em primeiro lugar, o autor/autora expõe, descritivamente, duas ou mais justificativas para o exercício da liberdade de expressão, as quais são referenciadas abstratamente como posições já anteriormente adotadas por nossa Suprema Corte, seguidas de menções esparsas e pouco sistemáticas de dispositivos constitucionais singulares, geralmente, desacompanhados da produção jurisprudencial do STF. Em um segundo momento, sem que haja qualquer explicação ou reconstrução interpretativa dos indícios políticos e normativos que sejam capazes de direcionar o leitor para o resultado, uma das justificativas descritas acima é eleita pelo autor/autora, uma de sua preferência (o que é mais provável), para explicar todas as maneiras de se exercer o direito em comento, bem como seus eventuais limites. Por fim, o terceiro passo consiste na colação das decisões do STF, expostas,

\footnotetext{
4 Os juristas brasileiros contemporâneos ainda reproduzem elementos da intelectualidade nacional cujas raízes remontam ao século XIX, quando ideias eram consideradas vanguardistas desde que acompanhadas de palavras bonitas ou da estampa de aprovação de algum autor estrangeiro, ainda que, por exemplo, esses juristas defendam ideias contraditórias ou que guardem pouco ou nenhuma correlação com a realidade prática do direito nacional. O argumento é inspirado e adaptado de Sérgio Buarque de Holanda, ao discorrer sobre o bacharelismo no Brasil (HOLANDA, 2014, p. 186-192).
} 
geralmente, a partir de sua ementa ou de seu resultado imediato, como via ratificadora da justificativa eleita no segundo momento.

A identificação da justificativa da liberdade de expressão brasileira não pode ser adotada abstratamente de antemão pelo pesquisador ou pesquisadora, uma vez que ele/ela precisará ser capaz de explicar a prática das instituições políticas do país, principalmente a do Supremo Tribunal Federal, sob pena de sua proposta operar como uma tese idealista ${ }^{5}$, para dizer o mínimo, sobre como nossas cortes deverão comportar-se ao lidar com casos sobre o tema, quando muito.

Nada obstante, o problema da inversão analítica de cunho idealista e a formulação de justificativas explicativas para a liberdade de expressão são úteis para a construção de eventuais posições protegidas pelo direito e para a definição de seus limites. Apenas para ficar em um único exemplo ilustrativo, o embate sobre a regulamentação do discurso de ódio que separa em cantos distintos Dworkin e Waldron reside nas distintas justificativas sobre a liberdade de expressão esposada por ambos. Um pesa nas tintas da liberdade individual de expressar conteúdos profanos, reforçando o componente de responsabilidade pessoal sobre a influência de uma ideia na ação individual e coletiva (DWORKIN, 2006, p. 319-321) e e, do outro lado, há o reforço do acento comunitário necessário em empreendimentos democráticos, os quais demandam a proteção de um estado de coisas que não torne a vida de um grupo estigmatizada ou inviável para o exercício de sua dignidade (WALDRON, 2012, p. 04-05).

A seguir, serão expostas as construções das justificativas sobre a liberdade de expressão trabalhada por seleta dogmática constitucional.

Gonet Branco, após exposição sintética das quatro justificativas elencadas acima, sugere que a liberdade de se expressar é "condição relevante para própria higidez psicossocial do pessoal”, guardando vínculos com sua sociabilidade, elemento "essencial ao ser humano" (MENDES; BRANCO, 2019, p. 268). André Ramos Tavares é enfático ao afirmar que a liberdade de expressão serve de meio para se atingir uma finalidade jungida à formação da autonomia individual, a qual se sobreporia a todas as demais. A liberdade de expressão, avalia em síntese o autor, deve se "prestar à realização pessoal" (TAVARES, 2019, p. 501-502). Fernandes (2014, p. 369) não chega a filiar-se a qualquer justificativa teórica de forma expressa, mas pontua que a liberdade de expressão tutela toda a mensagem passível de comunicação, sobre qualquer tema, "seja essa relevante ou não aos olhos do interesse público, ou mesmo dotada - ou não - de valor". Portanto, este autor adere à justificativa do interesse pessoal.

Sarlet (2015, p. 487-491) inicia sua conceituação da liberdade de expressão alardeando o que considera ser uma definição inclusiva. Em seguida, pontua que um dos principais fundamentos desse direito está na autonomia do indivíduo, mas, também, em uma dimensão social e política, com as condições e garantia da democracia, a fim de assegurar um livre mercado de ideias. Portanto, o direito fundamental assume uma feição política e transindividual. Sobre a interação entre livre expressão e democracia, o autor sustenta que ambos estão sob um condicionamento recíproco que assume "um caráter complementar, dialético e dinâmico". O constitucionalista identifica que a livre expressão representa um "valor central para um Estado Democrático de Direito e para a dignidade humana".

Regina Ferrari (2011, p. 588) expressa de forma mais contundente a relação de condicionamento recíproco entre democracia e livre expressão sugerida por Sarlet, ao conceder que o direito em comento serve como um

\footnotetext{
Se há um tópico capaz de unir pensadores que advogam ideologias antitéticas é a crítica feita aos intelectuais idealistas. Ainda que separados pela crença que depositavam no liberalismo como ideologia capaz de solucionar nossos problemas nacionais, Vianna (1987) e Holanda (2014) identificaram a perniciosa tendência de nossos intelectuais de importar ideias estrangeiras e tentar implementá-las, sem que as compreendessem totalmente, a uma realidade que, simplesmente, não era possível de ser explicada por elas ou, talvez, de recepcioná-las. Holanda nos fala de uma "crença mágica no poder das ideias" como uma espécie de escapismo motivado por um horror secreto a nossa triste realidade, que impulsiona a importação ideológica na esperança de que aquelas boas ideias se tornem, quem sabe, realidade algum dia (HOLANDA, 2014, p. 190-191). Sem ter que deixar de lado o elitismo e racismo que maculam suas teses, Vianna critica a crença de seus contemporâneos, tidos por ele como "marginais" e "idealistas utópicos", de que a solução para os problemas da realidade social brasileira estaria na edição de boas leis, o que tornaria desnecessário o estudo aprofundado das causas que as motivaram. A marginalidade desses juristas se caracterizaria pela sua divisão cultural, de acordo com a qual, haveria uma cultura local, que forma seu subconsciente coletivo; e a europeia ou norte-americana, a partir da qual retira suas ideias, diretrizes do pensamento e os critérios de julgamento políticos. As ideias se formam sobre uma base abstrata e logo são tidas como dogmas, os quais serão aplicados a uma realidade de todo inóspita (VIANNA, 1987, p. 16-21). A produção acadêmica jurídica atual, como referida no texto, dá continuidade a essa tradição no ambiente universitário ao tentar explicar nossa liberdade de expressão a partir de teorias formuladas com base em indícios políticos identificáveis na realidade de origem da tese e que podem não ser replicadas localmente. A importação é feita porque o mais importante nesse processo é apropriar-se do rótulo da ideia, estar seguro de sua origem estrangeira e da crença do importador de vincular-se ao seu significado.

6 Em verdade, Dworkin não exclui a justificativa instrumental, ao contrário, considera-a essencial para uma compreensão holística da liberdade de expressão, todavia, sustenta que ela é frágil e limitada, pois dá azo a um conjunto maior de restrições, além de não conseguir explicar todos os aspectos do exercício da livre expressão.
} 
instrumento de "realização pessoal e de formação de opinião democrática". Como consequência, informações falsas não merecem proteção constitucional, uma vez que sua incorreção possibilita a influência da opinião pública a ponto de "prejudicar o processo democrático".

Agra (2018, p. 223-225), por exemplo, sugere que a livre expressão encontra "sua fundamentação no princípio da autodeterminação humana, [...] de forma a garantir um melhor aperfeiçoamento da personalidade e permitindo a divulgação de suas ideias de forma ampla". No entanto, o autor reconhece a importância deste direito para a democracia e que há nele uma dimensão coletiva, mas não indica como elas se correlacionam ou qual a posição da jurisprudência do STF a respeito dessa inter-relação. Novelino (2016, p. 347) parece filiar-se à justificação dos interesses pessoais por sugerir ser esta uma liberdade "dirigida, sobretudo, ao Estado, impedindo-o de impor sanções para os que rejeitam opiniões amplamente aceitas ou de censurar discursos não aprovados pelo governo", o que incluiria discursos que possam causar dano ou perigo, a não ser quando tenham o potencial de "causar ações ilícitas".

A dogmática nacional parece atribuir maior peso à justificativa individual e de desenvolvimento pessoal da liberdade de expressão, uma vez que enfatiza sua importância para a autonomia individual do cidadão brasileiro. As outras justificativas assumem posição secundária, muito embora a ideia de reforço democrático ostente um honroso segundo lugar nas formulações teóricas. Uma conclusão parcial que pode extrair-se dessa investigação dogmática é a seguinte: a liberdade de expressão desempenharia, supostamente, no ordenamento constitucional brasileiro, a função de subsidiar o indivíduo com a capacidade de manifestar qualquer tipo discurso, valoroso ou não, virulento ou não, importante ou não para o desenvolvimento e fortalecimento da democracia.

Essa linha argumentativa intrínseca, não instrumental sugere a defesa dessa liberdade como elemento essencial contra a ação ou decisão política estatal. Dessa forma, a interpretação feita dos conteúdos e limites dessa liberdade deve estar condicionada, tão somente, a outros direitos fundamentais de igual importância no ordenamento constitucional, como o direito à honra. No entanto, é muito difícil extrair-se conclusões mais seguras sobre a interação entre esses direitos ou seus limites, uma vez que a construção dogmática segue o modelo idealista descrito linhas atrás.

Como opção metodológica contraposta, prefere-se ir aos precedentes do STF para coletar deles informações sobre como a Corte interpreta o direito à livre expressão, qual o lugar que ele ocupa dentro do conjunto dos demais direitos fundamentais e do regime democrático como um todo. Para evitar a investigação dos precedentes do tribunal ao longo de 33 anos de operação pós-88, em detrimento dos mais relevantes, que são os julgados produzidos pela atual $\mathrm{Corte}^{7}$, a pesquisa limitar-se-á a um período de quatro anos (2017-2020), em que sua composição se manteve estável.

\subsection{A justificativa jurisprudencial instrumental democrática}

Sem embargo da escolha metodológica deste artigo, de focar a investigação nos julgados da atual composição, um circunstanciado bosquejo pelos precedentes do tribunal que antecederam à pesquisa empírica proposta já demonstra que os ministros enxergam uma correlação umbilical entre livre manifestação do pensamento e a defesa de um regime político de corte democrático. Essa postura fica evidente em seu primeiro precedente plenário relevante pós-88 e, com maior destaque, em um dos seus mais importantes julgados sobre liberdade de imprensa decididos pela Corte.

Em 2007, a Corte derrubou decreto do Governador de Brasília que impunha restrições às manifestações públicas com aparelhos sonoros de qualquer espécie na praça dos três poderes e adjacências ${ }^{8}$. O relator do caso, Min. Lewandowski assentou, entre outros fundamentos, que a liberdade de expressão era fundamental para a democracia e que seu exercício dependia da possibilidade de mobilizações asseguradas pelo direito de reunião.

Poucos anos depois, o STF declarou não recepcionada a integralidade da lei de imprensa editada durante a Ditadura Militar em função de sua incompatibilidade espiritual com a nova ordem democrática. Na ocasião,

7 Santos (2020, p. 29) sustenta que os ministros se sentem constrangidos pelos precedentes da composição da qual fazem parte ou pelos votos proferidos por eles mesmos em ocasiões semelhantes, isto quer dizer que, os precedentes sedimentados de composições passadas do tribunal não exercem o mesmo tipo influência na argumentação dos ministros.Para não correr o risco de trabalhar com precedentes que pudessem não ser tão persuasivos para a atual composição, a análise inicia-se com a chegada do Ministro Alexandre de Moraes (mar/2017) e termina com a saída do Ministro Celso de Mello (out/2020).

8 ADI 1.969, DJe 31/08/2007. 
seguindo o relator neste ponto à unanimidade, os ministros destacaram que a imprensa livre desempenharia papel essencial na proteção do regime democrático. Para o relator, Min. Ayres Britto, a expressão institucional da liberdade de expressão é necessária para que se viabilize o controle social do poder 9 .

Por fim, as manifestações públicas de $2011 \mathrm{em}$ prol da descriminalização do uso da maconha não foram consideradas como apologia criminosa tão somente pela interpretação constitucional da corte que vinculou a liberdade de expressão e direito de reunião ao de petição, todos dentro de um mesmo conjunto de direitos. O Min. Celso de Mello interpretou as popularmente chamadas "marchas da maconha" como manifestações cívicas análogas ao direito de petição do cidadão feito às instâncias políticas oficiais, ou seja, como um, entre outros, instrumento popular característico da democracia direta. Em síntese, Celso de Mello estava seguro de que as marchas não foram feitas para estimular o consumo da droga, mas, pelo contrário, seriam uma mobilização política pensada e organizada defensora de mensagem de abolicionismo penal e de sensibilização do legislador nacional ${ }^{10}$.

A pesquisa jurisprudencial feita, a partir da análise individual dos votos dos ministros do STF (2017-2020), contesta o resultado da análise dogmática de que o fundamento constitucional da liberdade de expressão no Brasil seja o desenvolvimento individual do cidadão. Os ministros, seguindo a linha jurisprudencial do Tribunal, defenderam uma justificativa instrumental de fundo democrático ${ }^{11}$. Os ministros, portanto, não demonstraram discordâncias significativas sobre a função a ser desempenhada pela liberdade de expressão em nossa ordem constitucional. Ou seja, há um consenso entre eles sobre a importância dessa liberdade para a garantia e desenvolvimento da democracia liberal de 1988.

A superação de resquícios censórios da Ditadura ${ }^{12}$ e o fortalecimento do Estado Democrático de Direito despontam como os objetivos centrais a serem concretizados pela liberdade de expressão $0^{13}$. Ao relembrar que a decisão pela não recepção da lei de imprensa fora justificada por sua incompatibilidade sistêmica com a Constituição de 1988 em razão de seu espírito ditatorial, o Ministro Barroso defendeu que o STF tem desempenhado "um papel decisivo na expansão da liberdade de expressão em um país em que certa cultura autoritária e censória sempre prevaleceu [...]"14. Por outro lado, o Ministro Celso de Mello costuma reforçar em suas manifestações que a relevância da liberdade de expressão reside no fato de que sua positivação "representa elemento fundamental de garantia da integridade do regime democrático e de preservação de sua própria existência"15.

Com efeito, a construção jurisprudencial de uma justificativa instrumental para o exercício de um direito fundamental provoca questionamentos que afetam o sentido político da livre expressão no Brasil que precisam ser endereçados pela academia.

Em primeiro lugar, essa interpretação judicial sinaliza que o sentido e o conteúdo do direito fundamental em análise foram determinados pelas circunstâncias anteriores à constituinte. A prática censória do regime militar, as restrições ao exercício do discurso livre das pessoas e os ataques à imprensa fizeram com que o direito à liberdade de expressão da atual Constituição fosse encarado como uma viga de reforço ao regime democrático nascente, circunstância histórica e política que condiciona seu exercício ao interesse de temas tangentes a uma interpretação específica de nossa democracia constitucional ${ }^{16}$. Ou seja, esse direito, ainda que titularizado por pessoas, encontra suas funções precípuas no combate contra a censura estatal e nas manifestações que sirvam

ADPF 130, DJe 30/04/2009.

ADPF 187, DJe 15/06/2011.

Conclusão confirmada anteriormente por Koatz (2011, p. 442) e Morgado (2011).

Cf.,voto do Ministro Barroso na ADI 4451 (2018).

13 Nesse mesmo sentido, Macedo Jr.(2017. p. 280), The Brazilian Constitution is the result of the democratization process that followed the end of the authoritarian regime. For this reason, its main political rationale is based on the liberal idea that free speech is a central instrument for the protection of the democratic regime.

14 ADI 2566. No mesmo sentido, na cf., o voto do Ministro Fux no RE 685.493 (2020): "No Brasil, a liberdade de expressão assumiu especial relevância político-jurídica no contexto de redemocratização apresentando-se como direito fundamental crucial no novo marco constitucional de 1988 . A instauração do ambiente democrático pôs fim à prática de censura recorrentemente presente nos anos do regime militar [...]".

15 No mesmo sentido, na cf., o voto do Ministro Gilmar Mendes no HC 141.949 (2018): "Impende destacar que a liberdade de expressão consubstancia um dos mais valiosos instrumentos na preservação do regime democrático. O pluralismo de opiniões, a crítica, a censura, são vitais para a formação da vontade livre de um povo. [...] O Estado de Direito democrático não desconhece esse valor universal".

16 Os autores corroboram com a importância dada pela constituinte à liberdade de expressão. Rafael Koatz atesta que "a liberdade de expressão ganhou redobrado destaque" na constituinte (KOATZ, 2011, p. 392). 
ao interesse ou proteção do Estado democrático, em prejuízo à importância desta liberdade como campo de ação necessário ao desenvolvimento da personalidade individual ${ }^{17}$.

Essa conclusão ilustra o desencontro entre a justificativa centrada no desenvolvimento pessoal defendida preponderantemente pela dogmática, cuja linha de raciocínio é influenciada pela leitura liberal clássica de que direitos fundamentais são titularizados pelas pessoas em face do Estado, independentemente de sua relevância ou função a ser cumprida por eles; e, por outro lado, a posição jurisprudencial instrumental centrada na simbiose entre direitos fundamentais e a formação política e social do regime constitucional mais recente, a partir da qual direitos são constitucionalizados para que cumpram importantes funções determinantes para o sucesso da República (FAÚNDEZ, 2004, p. 88).

A visão instrumental do STF explica por que a liberdade de expressão dos cidadãos brasileiros: a) está submetida ou subordinada com respeito a preceitos do bom funcionamento da administração pública ${ }^{18}$; b) em sua vertente religiosa, não pode justificar a desestabilização de um pretenso padrão de harmonia entre as designações religiosas do país ${ }^{19}$; c) é elemento central para o fortalecimento da democracia ao favorecer a crítica de candidatos a cargos públicos por meio da sátira ou do humor ${ }^{20}$; d) é importante para garantir um debate livre de ideias no ambiente das universidades públicas ${ }^{21} ;$ e) garante que rádios comunitárias possam ser criadas para o exercício do proselitismo, como forma de assegurar o pluralismo de ideias ${ }^{22}$; f) é capaz de tolerar discursos racistas desde que amparados pela imunidade parlamentar e desferidos dentro de um contexto de crítica a políticas públicas ${ }^{23} \mathrm{e}$ f) justifica a extensão da imunidade parlamentar a ministros de estado, para que estes possam exercer controle sobre a administração pública ${ }^{24}$.

Ao interpretar a liberdade de expressão como um elemento que compõe as bases do Estado constitucional, e não como uma liberdade individual garantidora de um campo de atuação sujeito à disposição dos cidadãos brasileiros para seu livre desenvolvimento pessoal, independentemente do valor ou sentido da expressão, a Corte cria um rigoroso parâmetro político para aferir a legitimidade do conteúdo da manifestação de uma pessoa. Dito em outras palavras, a proteção judicial de um pensamento externalizado dependerá da análise que a Corte fizer sobre seu cumprimento, ou não, da função de resguardo à democracia constitucional brasileira desempenhada pela liberdade de expressão.

A preponderância da interpretação instrumental no Brasil não necessariamente exclui a justificativa calcada na autonomia individual. É preciso concordar-se com os autores que sustentam a necessidade de trabalhar-se com alguma forma de justificativa múltipla ou complexa, no entanto, essa saída transigente não implica a atribuição de valores equivalentes a qualquer uma delas ${ }^{25}$. A proteção da democracia não explica por que as artes literárias, cênicas ou plásticas são, por exemplo, protegidas no Brasil, cobertura que apenas a justificativa focada no desenvolvimento pessoal pode oferecer. No entanto, para o direito constitucional brasileiro, a produção artística baseada na liberdade de expressão em sua vertente individual encontrará seus limites nos objetivos políticos democráticos a serem cumpridos pelo direito fundamental26.

17 Isso não significa dizer que outras justificativas não puderam ser encontradas nas manifestações individuais dos ministros, os quais, por vezes iniciavam sua argumentação ecoando a perspectiva doutrinária intrínseca, mas terminavam atribuindo maior peso à justificativa democrática. Portanto, sem a pretensão de resolver-se a tensão entre interesse individual e coletivo que permeia a liberdade de expressão neste trabalho, basta afirmar para o momento que há uma acentuada ênfase de uma justificativa democrática em detrimento das demais. Faúndez (2004, p. 93) fala, por exemplo, em um direito de suas dimensões - individual e social. Em seu aspecto social, o direito cumpriria a funções específicas dentro do arranjo político analisado, mas, geralmente, tais objetivos visam à proteção da democracia.

18 ADPF 496 (2020). Conferir trecho de voto do Min. Barroso ao defender o crime de desacato: "Não se trata de conferir um tratamento privilegiado ao funcionário público. Trata-se, isso sim, de proteger a função pública exercida pelo funcionário, por meio da garantia, reforçada pela ameaça de pena, de que ele não será menosprezado ou humilhado enquanto se desincumbe dos deveres inerentes ao seu cargo ou função públicos".

19 HC 146.303 (2018).

20 ADI 4.451 (2018).

ADPF 548 (2020).

ADI 2.566 (2018).

Inq. 1.694 (2019).

RE 685.493 (2020).

25 Um ponto a ser aprofundado em estudos posteriores é o seguinte: a justificativa sincrética da liberdade de expressão pode funcionar como uma carta coringa à disposição dos ministros da corte na escolha de uma solução de um conflito entre direitos fundamentais, a ser utilizada a depender da preferência do magistrado. Voltaremos a esse ponto posteriormente.

26 O argumento se inspira nas conclusões de Dworkin (2006, p. 319-321) sobre as justificativas instrumentais e intrínsecas da Primeira Emenda Trilhando o caminho oposto ao apresentado neste estudo, Dworkin explica que os argumentos não são incompatíveis, mas o instrumental é mais fraco e incompleto quando comparado ao intrínseco. Mais fraco, porque a vinculação a uma meta a ser cumprida pode servir para limitar o direito, em vez de garantir-Ihe maior proteção. Ademais disso, é incompleta porque não explica importantes manifestações tradicionalmente ancoradas pela livre expressão (artes, ciência, etc.). 


\subsection{A instrumentalidade democrática poliárquica}

Nenhum ministro preocupou-se em explicar o modelo de democracia ou de Estado Democrático de Direito esposado em seu voto (bem como o direito de proteção constitucional), no entanto, será adotado neste escrito como um modelo simples capaz de albergar as mais diversas visões dos ministros. É muito provável que em seus votos os ministros estejam trabalhando com uma noção de democracia representativa próxima do modelo formulado por Dahl, para explicar a inserção desse regime político na modernidade, a poliarquia. Com o empréstimo do conceito não se pretende sugerir que o STF tenha incorporado a tese de Dahl de forma consciente ou inconsciente, mas sim que ela possa ajudar a entender o que a Corte quer dizer quando reitera a importância da livre expressão para a democracia sem aprofundar-se no tipo de regime político em jogo.

Para Robert Dahl (1989, p. 220-221, a poliarquia é uma ordem política que garante cidadania à maior proporção de adultos, bem como direitos que oportunizam a oposição política e o controle do mandato dos governantes ${ }^{27}$. $\mathrm{O}$ conteúdo dessas duas características das poliarquias pode ser especificado a partir da presença de sete instituições políticas: 1) autoridades eleitas; 2) eleições livres e justas; 3 ) sufrágio inclusivo; 4) direito de concorrer a cargos eletivos; 5) liberdade de expressão; 6) meios alternativos de informação e 7) liberdade de associação.

A liberdade de expressão na poliarquia é necessária para que o cidadão possa se expressar, sem temer punições severas sobre questões políticas, as quais incluem a crítica aos mandatários, ao governo, ao regime, à ordem socioeconômica e à ideologia prevalecente. O direito à livre expressão é uma das ramificações institucionalizadas do direito moral ao autogoverno, uma vez que habilita as pessoas a participarem efetivamente do governo e à obterem uma compreensão adequada dos debates (CARBONELL, 2011, p. 92). Em razão dessa relação umbilical, uma violação à liberdade de expressão de uma pessoa representará uma grave ameaça a todo o processo de consolidação democrática no Brasil.

O entrelace entre o regime democrático e o exercício de um direito fundamental estabelecido pelo STF significa, ademais, que o campo de proteção do discurso de um cidadão está adstrito tão somente ao necessário para viabilizar o exercício de suas manifestações relativas à oposição política. Ou seja, não se trataria de um direito amplo, genérico e irrestrito contra quaisquer decisões políticas estatais ou mesmo uma garantia individual de produzir ou consumir qualquer tipo de manifestação de pensamento, mas sim um direito que pretende resguardar uma decisão política fundamental de interesse social, que seria a leitura poliárquica sobre o ideal de redemocratização instaurado pela Constituição de 1988.

Ao mesmo tempo, a interpretação feita pelo STF sobre o sentido da expressão politicamente manifesta deve respeitar a tradição que, de forma corrente e compartilhada no senso comum, explica a formação do Estado e da sociedade brasileira. Com base nessa premissa adicional, é possível identificar a existência de uma postura jurisprudencial menos protetiva às manifestações desferidas contra a igreja católica, seja para justificar a criminalização de manifestações contra essa fé, pois elas militariam contra a natureza harmônica e equilibrada do brasileiro em relação à convivência pacífica entre as religiões ${ }^{28}$; seja pelo fato de a liberdade de expressão fundamentar a exigência de ensino confessional católico em escolas públicas ${ }^{29}$. Ambas as decisões podem ser

27 A oposição política é tida por Dahl como um elemento indispensável para um bem-sucedido processo de democratização, reservado o termo "democracia" para um sistema político completamente responsivo a todos os seus cidadãos (DAHL, 1971, p. 01-02).

28 HC 146.303, cf., voto do Min. Dias Toffoli: "O direito à liberdade religiosa é, portanto, em grande medida, o direito à multiplicidade de crenças/ descrenças religiosas, que se vinculam e se harmonizam - para a sobrevivência de toda essa multiplicidade de fés protegida constitucionalmente - na chamada tolerância religiosa. [...] Compreendo que este tipo de agir não se enquadra no direito à liberdade de expressão; não se enquadra, com a devida vênia, na ideia de liberdade religiosa; muito pelo contrário. Trata-se de manifestação que atinge diretamente o direito de crença do outro e a própria integridade de conduta de seus fiéis [...] é dever deste Poder [Judiciário] promover a aplicação do princípio da liberdade religiosa em absoluta sintonia com a inspiração que promove essa tradição".

$29 \mathrm{ADI} 4439$, cf., voto do Min. Alexandre de Moraes: "interdependência e complementariedade das noções de Estado Laico e Liberdade de Crença e de Culto são premissas básicas para a interpretação do ensino religioso de matrícula facultativa prevista na Constituição Federal, pois a matéria alcança a própria liberdade de expressão de pensamento sob a luz da tolerância e diversidade de opiniões [...]. Da mesma maneira que o ensino religioso ministrado com absoluto respeito ao referido binômio Estado Laico/Consagração da Liberdade Religiosa, a prestação da assistência religiosa nesses estabelecimentos compatibiliza a existência do Estado Laico e a previsão, como direito subjetivo individual do preso ou internado à sua liberdade religiosa, mediante a prestação de assistência religiosa e preservando-se, igualmente, a plena liberdade daqueles que não professam nenhuma crença religiosa". 
explicadas pela importância histórica e política da igreja católica na formação do Brasili30 e pela maioria dos ministros professarem essa mesma fés ${ }^{31}$.

Ainda nessa seara, a dupla justificativa instrumental, poliárquica e tradicionalista, explica a resistência da Corte em caracterizar as falas de Jair Bolsonaro como racistas, ao classificá-las como meras manifestações decorrentes do seu direito de oposição política. Dessa forma, para o STF, ao destratar povos indígenas, ao defender abertamente a criação de dificuldades adicionais na titulação de suas terras, e ao atribuir aos quilombolas características animalescas, em verdade, o atual Presidente estaria apenas a criticar as políticas públicas de demarcação de terras propostas por governos anteriores ${ }^{32}$.

A decisão do STF, no caso, classificou um discurso discriminatório e preconceituoso como uma manifestação inserida na noção poliárquica de liberdade de expressão, porquanto as frases do réu estariam protegidas pela natureza de enfrentamento a uma política pública. Hipótese reforçada, ademais, pelo fato de a Corte acobertar o discurso de Bolsonaro com o manto da imunidade parlamentar. Uma escolha decisória que pressupõe que manifestações racistas seriam essenciais ao conflito político e democrático por dizerem respeito ao regular exercício do mandato de um parlamentar.

Por outro lado, a postura da Corte também expressa o receio do tribunal em tomar uma decisão condenatória que taxe alguém como uma pessoa racista, sentença criminal que abalaria a tese da convivência racial harmoniosa no país ${ }^{33}$ e, para evitar essa pecha, cria-se, por parte da Corte, teses engenhosas para elevar o padrão de identificação de um discurso racista ${ }^{34}$.

A tese da liberdade de expressão como proteção de uma dimensão poliárquica e que espelha uma tradição questionável da formação do Estado brasileiro, não se afasta dos pressupostos a partir dos quais são formuladas as teorias explicativas sobre a Primeira Emenda à Constituição dos Estados Unidos da América. Jornalistas, filósofos e juristas convergem na afirmação de que o sentido da proteção ao discurso se alterou ao longo da história, cuja feição mais recente está ligada à proteção dos movimentos por direitos civis ${ }^{35}$. Sunstein (1999, p. 173-177), por

30 Cf., sobre a indistinção entre Estado e Igreja Católica no período colonial e a importância dessa parceria para a formação do Estado e cultura brasileiros (FAUSTO, 2010, p. 59-62). O catolicismo romano não apenas foi a religião oficial do Brasil até 1890, como ajudou a formar o conjunto de valores essenciais ao Brasil. (DA MATTA, 1986, p. 116). Freyre (2006, p. 90-92) atribuiu ao catolicismo português reproduzido na colônia o "cimento de nossa unidade", cuja educação e moral injetaram substância num corpo vazio.

31 Da formação plenária analisada neste trabalho, sete ministros são católicos (Dias Toffoli, Marco Aurélio, Gilmar Mendes, Ricardo Lewandowski, Cármen Lúcia, Edson Fachin e Alexandre de Moraes). Dois são judeus (Luiz Fux e Roberto Barroso) e não são conhecidas as crenças da ministra Rosa Weber https://www.jb.com.br/pais/2019/06/1003139-para-membros-do-supremo--religiao-deles-e-irrelevante-para-atividade-de-ministro.html. Acesso em 15 de outubro de 2020.

32 Voto do Min. Marco Aurélio no Inq. 4.694 (2018): "Percebam que as falas referidas na peça acusatória estão vinculadas ao contexto de demarcação e proveito econômico das terras, sendo descabido confundir o interesse na extinção ou diminuição de reservas indígenas ou quilombolas com a supressão e eliminação dessas minorias. O contexto - repita-se, vinculado à política de demarcação de terras -, além de não se inserir no conteúdo proibitivo da norma, configura manifestação política que não extrapola os limites da liberdade de expressão". No mesmo sentido, o voto de Alexandre de Moraes: "Por mais grosseiras, por mais vulgares, por mais desrespeitosas, as declarações foram dadas em um contexto de crítica política a instrumentos governamentais e a políticas governamentais realizadas em relação a quilombolas e aos refugiados, aos estrangeiros, não tendo havido, desvio de finalidade ou extrapolamento que afastassem a incidência da inviolabilidade material".

33 A sombra de Freyre projeta uma sufocante e constante sobra nos casos em que a corte precisa lidar com relações raciais no Brasil. Maurício Correa recorreu, expressamente, ao autor no caso Ellwanger (2003) e as ideias do sociólogo pareceram influenciar o critério rigoroso formulado pelos ministros para que as falas de Bolsonaro fossem tidas como racistas: o então Deputado precisaria ter sugerido a destruição física ou menosprezar o sofrimento dos negros durante a escravidão. O teste para identificar um discurso racista parece reforçar a tese de que há uma convivência social tensa, antagônica, mas que se equilibra entre as diversas raças e etnias. (FREYRE, 2006, p. 116-117). Portanto, meras palavras, grosserias ou vulgaridades não seriam suficientes para configurar o racismo em uma sociedade harmônica, cujo equilíbrio antagônico se romperia apenas com a defesa do extermínio físico do outro grupo. Questionamo-nos quando essas hipóteses irão ocorrer em um país de racismo velado.

34 Gislene Santos (2015, p. 184-207) identificou um padrão semelhante ao analisar casos de racismo e injúria racial julgados pela justiça paulista entre 2011 e 2013. A pesquisadora identificou, inicialmente, que o judiciário entendeu que ofensas depreciativas que atribuem ao negro percepção de animalidade ("macaco"), falta de asseio ("preto sujo") e falta de capacidade intelectual ("negro burro") representariam ataques à honra do ofendido, portanto injúrias raciais, e não faces de um racismo que retira do negro a condição de ser humano, estabelecem um grau de hierarquia e poder e reproduzem ofensas que se mantiveram desde a escravidão. A postura judicial de desclassificação do racismo para injúria, o fato de minimizarem as agressões como normais ou naturais são indicativas de como as relações raciais operam no Brasil, onde há um desejo de que a "raça não conte". Para autora, a postura judicial espelha "a seletividade na construção dos fatos jurídicos em acordo com um discurso sobre a brasilidade formulada em torno da ideia da cordialidade, da harmonia, da inexistência de qualquer forma de discriminação e do horror ao preconceito e ao racismo; um discurso que exalta as qualidades do povo brasileiro como ordeiro, humano, bondoso, solidário, amigo [...], mas que, simultaneamente, valoriza que cada um permaneça em seu lugar sem questionar as hierarquias raciais e sociais existentes". Outra pesquisa demonstrou como, por vezes, a injúria racial é descaracterizada em favor da injúria simples, mesmo quando ofensas de cunho racial são proferidas. Tribunais consideraram que chamar uma pessoa de "preta sem nome" ou "negra safada" não é demonstração cabal de que se pretenda ofender a etnia da ofendida. Machado e outras concluem que "há uma resistência a se reconhecer o insulto racista como uma forma de racismo, a despeito das mudanças na lei" (MACHADO; LIMA; NERIS, 2016, p. 11-28).

35 Anthony Lewis (2011, p. 09-13), um dos maiores conhecedores da história da Primeira Emenda, reconhece que o sentido da proteção da liberdade de expressão se alterou ao longo do tempo na realidade estadunidense. Sua tese é a de que a complexidade contemporânea comum aos direitos e obrigações decorrentes da afamada emenda se adaptaram ao desenvolvimento da cultura e sociedade americanas. As decisões dos juízes da Suprema Corte concorreram, decisivamente, para a concretização dessa evolução. 
exemplo, equaciona a disputa interpretativa sobre a $1^{\text {a }}$ Emenda como o embate entre duas tradições sobre o propósito (point) da liberdade de expressão: uma voltada ao livre mercado de ideias e outra preocupada com a deliberação democrática.

A última se assemelha, mas não se iguala, aos resultados até aqui explorados. A leitura da liberdade de expressão norte-americana como a garantia de uma liberdade democrática surge, principalmente, a partir dos trabalhos de teóricos liberais de esquerda, que passaram a questionar a permissiva doutrina da Suprema Corte a partir dos anos 70. A preocupação desse conjunto de autores era inserir um argumento igualitário dentro de um debate preocupado, exclusivamente, com os interesses individuais. Para eles, problemas na distribuição de recursos políticos acentuados pelo capitalismo irrefreado afetam a forma pela qual a mensagem e as manifestações de certos grupos políticos e sociais impactam o discurso público. Dessa forma, a intervenção estatal faz-se necessária para restabelecer o equilíbrio nessa disputa política, entretanto, essa postura só pode justificar-se dentro de uma argumentação que não toma como sinônimo de liberalismo a ausência total de interferência estatal e que, ademais disso, entende como viável restringir a justificativa da autonomia individual em prol de algum objetivo coletivo.

Para Sunstein (1999), os que advogam por uma leitura deliberativa da liberdade de expressão prezam a igualdade política e uma cultura cívica compartilhada. Dessa forma, o mercado de ideias não está imune de controle estatal, muito embora limites a ele sejam impostos, de canais que garantam o funcionamento escorreito da democracia. Então, ao mesmo tempo em que visam garantir diversidade de pontos de vista, podem promover o discurso político ao custo de outras formas discursivas.

Fiss (1986, 1.409-1.410), por exemplo, sugere que a tradição criada pela Suprema Corte sobre a liberdade de expressão que protege, irrestritamente, o manifestante não é suficiente para dar conta dos problemas da sociedade moderna, cujos conflitos discursivos não se limitam à proteção da pessoa que protesta na esquina com cartazes em riste. Em seu entender, o propósito da liberdade de expressão não é a realização da autonomia individual, mas a preservação da democracia e do direito de alguém, como uma pessoa, de decidir que tipo de vida deseja viver. A autonomia é protegida não por conta de seu valor intrínseco, mas como um meio ou instrumento da autodeterminação coletiva ${ }^{36}$.

Em alguns votos lançados em plenário, no entanto, foi possível identificar um descuidado sincretismo entre as justificativas na leitura de alguns ministros, os quais defenderam uma justificativa constitucional acolhedora de todas, ou quase todas, as justificativas oferecidas pela doutrina. Portanto, para alguns ministros, à livre expressão se atribuiria posições políticas díspares e, talvez, inconciliáveis.

Tabela 01: Ministro do STF e sua justificativa para a liberdade de expressão (2017-2020)

\begin{tabular}{l|l|l}
\hline \multicolumn{1}{c|}{ Ministro/ Ministra } & \multicolumn{1}{c}{ Justificativa } & \multicolumn{1}{c}{ Julgado } \\
\hline Alexandre de Moraes & Democrática/Mercado de ideias & ADI 4.451 (2018) \\
\hline Cármen Lúcia & Democrática & ADPF 548 (2020) \\
\hline Celso de Mello & Democrática & Rcl 15.243/RJ (2019) \\
\hline Dias Toffoli & Democrática & HC 146.303 (2018) \\
\hline Edson Fachin & Democrática & ADI 2.566 (2018) \\
\hline Gilmar Mendes & Democrática & HC 141.949 (2018) \\
\hline Luiz Fux & Mercado de ideias/ Democrática & Rcl 28.747/MS (2018) \\
\hline Marco Aurélio & Dignidade individual/Mercado de ideias/Democrática & RE 685.493 (2020) \\
\hline Ricardo Lewandowski & Democrática & ADPF 548 (2020) \\
\hline Roberto Barroso & Democrática/Dignidade individual/Mercado de ideias & RCL 22.328/RJ (2018) \\
\hline Rosa Weber & Democrática & ADPF 496 (2020) \\
\hline
\end{tabular}

Fonte: Elaboração do autor

36 Sua abordagem enxerga problemas na estrutura social contemporânea, os quais somente poderão ser solucionados por uma intervenção estatal capaz de enriquecer o debate público ao resguardar as condições para uma autodeterminação coletiva livre (FISS, 1996, p. 20). 
Nada obstante a utilização de uma fundamentação saliente instrumental de base democrática, o índice de divergência entre os ministros no julgamento de casos concretos ainda é bastante expressivo, o que pode significar que o motivo dessa discordância interpretativa pode estar nos testes empregados por eles para a solução de conflitos entre direitos fundamentais.

\section{Os testes jurisprudenciais para a solução de conflitos constitucionais: posição preferencial ou proporcionalidade?}

As cortes encarregadas de tomar decisões sobre temas constitucionais empregam padrões normativos para racionalizar sua interpretação constitucional em temas sensíveis e controversos. Talvez o padrão mais difundido entre elas para julgar casos sobre direitos fundamentais seja o da proporcionalidade (SWEET; MATHEWS, 2008). Outros padrões incluem o balanceamento e o teste do escrutínio estrito, apenas para ficar em alguns exemplos. O uso desses padrões em casos controversos não garante a certeza de uma uniformidade interpretativa ou, para a audiência da Corte, a previsibilidade quanto ao resultado de uma demanda. A certeza reside, tão somente, na aplicação de um padrão correspondente ao tipo de conflito constitucional levado à Corte.

O processo deliberativo do STF inviabiliza a formulação de testes, doutrinas ou padrões ${ }^{37}$ consensualmente compartilhados por todos os ministros para solucionar conflitos de direitos fundamentais. A apresentação de votos personalistas que não interagem entre si - elaborados a partir de fundamentos diversos, mas que convergem no resultado -, enfraquecem a caracterização do acórdão da Corte (e das turmas) como o produto de um órgão colegiado que concentra esforços para tornar o processo de tomada de decisões constitucionais mais racional e

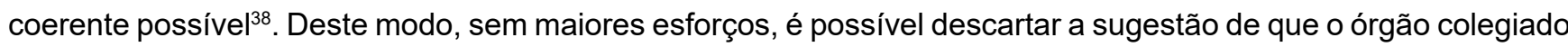
trabalhe com padrões normativos compartilhados e que podem ser atribuídos ao seu esforço interpretativo coletivo. Todavia, essa conclusão não pode ser rejeitada de pronto em uma análise individualizada dos posicionamentos dos ministros. Ademais, a resposta para explicar caminhos paralelos que se cruzam, por vezes, na conclusão pode estar na adoção de padrões normativos diferentes.

A dogmática constitucional aborda o tema da interpretação a partir de uma metodologia sincrética e pouco útil. Em vez de investigar os padrões criados pelo STF ou por seus ministros, a pesquisa dogmática opta por importar listas de critérios interpretativos para que sejam, por sorte, estratégia ou acaso, referenciadas em decisões constitucionais. Os princípios interpretativos da Constituição são contraditórios entre si e não parecem ter ganhado adesão significativa na jurisprudência da Corte (SILVA, 2005). De mais a mais, esses padrões não são exclusivos para casos sobre liberdade de expressão, bem como os ministros parecem selecionar o marco teórico de acordo com o resultado que pretendem alcançar.

A formulação de testes judicialmente manejáveis para a solução de conflitos que envolvam a liberdade de expressão é mais corriqueira em trabalhos monográficos ou artigos especializados do que em manuais ou cursos de direito constitucional, motivo que justifica sua ausência nesse momento do artigo. Dois desses testes merecem destaque por encontrarem eco na jurisprudência da Corte: o da proporcionalidade e o da posição preferencial ${ }^{39}$.

Em síntese operativa para fins de investigação, a aplicação do teste da proporcionalidade indica que não há nenhum aspecto inerente à natureza da livre expressão enquanto direito fundamental capaz de situá-la em posição diversa da ocupada pelos demais direitos, principalmente, aqueles relativos à personalidade (imagem,

37 Uma doutrina pode ser uma moldura de julgamento, um conjunto de regras, etapas procedimentais a serem seguidas pela corte ou testes a serem empregados para a revisão de uma lei ou política pública, muitas vezes estabelecida por meio de um precedente. Uma doutrina surge quando uma corte estrutura uma moldura decisória e a aplica em casos semelhantes. (TILLER, 2006, p. 518). Testes na Suprema Corte dos Estados Unidos são, inicialmente, um critério o qual uma política pública deve cumprir para que seja constitucionalmente permissível e, em segundo lugar, determinam quem carregará o ônus probatório, ou seja, quem deverá justificar a constitucionalidade da medida. Os testes são criados, modificados ou descartados pela Corte ao longo do tempo (VAN GEEL, 2007, p. 81-93).

38 André Rufino do Vale (2013, p. 331-337) identifica os mesmos problemas no processo decisório do STF, como: a) problema de argumentação: ausência de debates construtivos e efetiva troca de argumentos; b) problemas de fundamentação: os votos são escritos para convencimento do público externo e não dos próprios ministros (demonstração de erudição individual); c) problemas de tomada de decisão: a decisão é constituída a partir da mera soma dos votos e não de um acordo racionalmente construído deliberativamente; d) problemas de publicação das decisões: da soma dos votos, a sentença se apresentará como um "Frankstein" argumentativo; e) problema de diálogo institucional: os problemas no processo decisório dificultam a delimitação de uma posição institucional do tribunal capaz de dialogar com os outros poderes.

39 Como exemplo de um interessante padrão deixado de fora, conferir o teste da capacidade comunicativa de Ivar A. Hartmann (2018). Segundo o autor, antes de realizar sua atividade ponderativa, o judiciário deverá avaliar, a partir do direito à igualdade, o alcance do poder comunicacional das partes envolvidas. O desequilíbrio comunicativo seria um elemento para que se averigue, no caso, se houve ou não, violação ao direito à honra de uma pessoa. 
honra, etc.). Dessa forma, em razão da inexistência de hierarquia entre normas constitucionais, na hipótese de conflitos entre direitos fundamentais, apenas elementos fáticos do caso concreto serão capazes de oferecer ao órgão julgador elementos suficientes para que formule seu juízo de proporcionalidade.

O teste da posição preferencial, por sua vez, sugere que a liberdade de expressão desfruta de uma vantagem não compartilhada com outros direitos fundamentais, principalmente os resultantes da personalidade, uma vez que a aplicação deste teste previne a existência de conflitos ao, antecipadamente, declarar que a primeira liberdade desfrutará de preponderância em um caso concreto ${ }^{40}$.

É possível, jurisprudencialmente, posicionar os ministros do STF em dois campos, tomando por base os testes por eles avençados para solucionar conflitos que envolvam a liberdade de expressão. Se tomarmos como ponto de referência o mais importante precedente sobre liberdade de expressão da história recente do tribunal, a ADPF 130, ambos os campos podem ser representados pelos votos dos Ministros Ayres Britto, defensor da posição preferencial da liberdade de expressão ao taxá-la como um "sobredireito", e Menezes Direito, que sugere inexistir base constitucional para defender-se a posição preferencial e que conflitos entre liberdade de expressão e outros direitos, todos derivados da dignidade humana, se resolvem por meio do teste da proporcionalidade.

Tabela 02: Ministro do STF e teste jurisprudencial para a liberdade de expressão (2017-2020)

\begin{tabular}{l|l|l}
\hline \multicolumn{1}{c|}{ Ministro/ Ministra } & \multicolumn{1}{c}{ Teste } & \multicolumn{1}{c}{ Julgado } \\
\hline Alexandre de Moraes & Proporcionalidade & ADPF 496 (2020) \\
\hline Cármen Lúcia & Posição preferencial & Rcl 42.143 MC (2020) \\
\hline Celso de Mello & Posição preferencial & Rcl 15.243/RJ (2019) \\
\hline Dias Toffoli & Proporcionalidade & HC 146.303 (2018) \\
\hline Edson Fachin & Posição preferencial & ADI 2.566 (2018) \\
\hline Gilmar Mendes & Proporcionalidade & HC 141.949 (2018) \\
\hline Luiz Fux & Posição preferencial & Rcl 28.747/MS (2018) \\
\hline Marco Aurélio & Posição preferencial42 & RE 685.493 (2020) \\
\hline Ricardo Lewandowski & Proporcionalidade & Rcl 24.954/MG (2017) \\
\hline Roberto Barroso & Posição preferencial & RCL 22.328/RJ (2018) \\
\hline Rosa Weber & Proporcionalidade & ADPF 496 (2020) \\
\hline
\end{tabular}

Fonte: Elaboração do autor

É bem verdade que votos antigos dos Ministros decanos, Celso de Mello e Marco Aurélio, já demonstravam suas intenções de atribuir uma maior força à liberdade de expressão ${ }^{44}$, no entanto, a expressão "posição preferencial" parece ter sido inserida no léxico da corte por meio do Ministro Luis Roberto Barroso ${ }^{45}$ e passou a figurar nos votos mais recentes daquele par de ministros.

A partir da análise dos votos, foi possível identificar que a Corte, em sua atual composição (2017-2020 ${ }^{46}$, está dividida quanto ao teste a ser empregado para solucionar casos relativos à livre expressão, conclusão que oferece uma base um pouco mais sólida sobre a compreensão dos ministros acerca do tema, do que a justificativa

40 Ingo Sarlet (2019, p.1.215-1.217), por exemplo, acredita que essa é a leitura de maior destaque no Brasil e, particularmente, proeminente no STF (CHEQUER, 2011). Para uma posição contrária, sugere-se que a tese da posição preferencial não é a predominante no direito brasileiro. Cf. Koatz (2011, p. 402) e Morgado (2011, p. 55).

41 Decisão Monocrática, DJe 09/09/2020

42 Interessante notar o possível afastamento de Marco Aurélio de sua compreensão sobre a posição da liberdade de expressão em nossa ordem constitucional desde sua manifestação doutrinária a respeito do tema em 2005 . Na ocasião, o ministro vinculava-se à leitura instrumental de natureza democrática ao defender que o direito não protege cegamente ou desproporcionalmente a autonomia de ideias individuais, as quais têm a força de "podar, de maneira erosiva, a própria democracia" (MELLO, 2005. p. 600-601).

43 Decisão Monocrática, 29/9/2017.

44 Marco Aurélio no caso HC 82.424/RS (2003) e Celso de Mello ADPF 187 (2013).

45 O Ministro defendeu essa interpretação em trabalho acadêmico publicado em 2004 (BARROSO, 2004, p. 20).

46 Nos casos colegiados julgados no período, não foi possível fazer uma avaliação segura sobre o posicionamento dos Ministros Cármen Lúcia e Ricardo Lewandowski. Para não fugir, tanto, da proposta metodológica inicial, recorreu-se às manifestações monocráticas deles para aferir quais os testes empregavam. No entanto, suas compreensões mais profundas sobre o tema podem ser consultadas nas ADls 4815 (2015) e 1969 (2007), respectivamente. 
para o exercício do direito em análise, conforme o visto em 1.1 e 1.2. Ou seja, como aventado anteriormente, os ministros que se enquadram na categoria da "proporcionalidade" demandam uma análise mais acurada sobre outros fatores para decidir em favor da livre manifestação. Ao passo que, para os que advogam a tese da posição preferencial, é muito provável que, independentemente do conflito levado à Corte, a decisão será favorável ao exercício da liberdade de expressão.

Cruzados os dados sobre a justificativa e os testes, será possível perceber que os ministros - que inadvertidamente atribuíram diferentes justificativas à liberdade de expressão, para além da democrática estão mais propensos a adoção do teste da posição preferencial. Uma postura decisória que faz sentido, pois a vinculação do direito à justificativa democrática reduz seu conteúdo constitucionalmente protegido e aumenta o campo do escrutínio da Corte. Justificativas de natureza mercadológica e individualistas tendem a conferir proteção constitucional a uma quantidade maior de discursos, favorecendo sua possível posição preferencial.

Nada obstante a possibilidade de identificar testes claros nos votos dos ministros singularmente considerados, isso não significa que, de um lado, haja um comprometimento completo dos ministros com a ideia de posição preferencial ou de proporcionalidade e que, por outro,seja possível, por essa razão, distinguir com clareza o conteúdo de cada um desses testes.

Os mais vocais defensores do teste da posição preferencial na Corte, os Ministros Barroso ${ }^{47}$ e Fux ${ }^{48}$, por exemplo, não se comprometeram com a sobreposição da liberdade de expressão em todo e qualquer caso. Os ministros falam, por exemplo, sobre a necessidade de aplicar-se o teste da proporcionalidade em alguns momentos ${ }^{49}$ ou, mesmo que a livre expressão seja um direito preferencial prima facie, cuja incidência definitiva dependerá das circunstâncias do caso. A influência de ambos está em precedentes da Suprema Corte dos EUA $\mathrm{A}^{50}$, todavia, o peso abstrato do parâmetro criado no direito norte-americano diminui quando ambos inserem a necessidade de mecanismos de ponderação ou de proporcionalidade como complementação ao teste da posição preferencial.

O teste da posição preferencial fez parte do arsenal interpretativo da Suprema Corte no período entreguerras, mas perdeu importância durante a Guerra-Fria, época em que a Corte passou a adotar uma interpretação mais conservadora da Primeira Emenda (EPSTEIN; WALKER, 2010, p. 211). Inicialmente, a adoção do teste sugeria uma ordenação hierárquica de valores constitucionais, exatamente para afastar o teste da razoabilidade aplicável para avaliar leis que, eventualmente, restringissem direitos fundamentais (SICKAL, 1961, p. 478). A doutrina nunca foi aceita, confortavelmente, pela maioria da corte no período de sua vigência (1937-1949) e encontrava no Juiz Frankfurter seu mais contundente opositor. Entre as razões que podem explicar o abandono do teste, destacam-se: 1) alterações na composição da Corte; 2 ) resistência dos juízes em relação à doutrina das liberdades preferenciais e a 3) alteração no ambiente político externo (guerra fria e repressão do comunismo nos EUA) ${ }^{51}$. Em substituição, a Corte voltou a empregar o teste do balanceamento.

Se a Suprema Corte norte-americana não voltou a empregar o teste da posição preferencial, que beirava o absolutismo, é bem verdade que seu espírito influencia sua prática contemporânea mais eclética de combinar testes que foram desenvolvidos ao longo dos anos ((EPSTEIN; WALKER, 2010). Essa conclusão significa que ela não desmerece o alto relevo que a Constituição atribui à Primeira Emenda, mas reconhece que a lei pode imporIhe restrições, desde que passem pelo teste do escrutínio estrito (FALLON JR, 2019, p. 22).

47 "Não obstante, a mera preferência da liberdade de expressão (ao invés de sua prevalência) decorre do fato de que nenhum direito constitucional é absoluto, tendo em vista que a própria Constituição impõe alguns limites ou algumas qualificações à liberdade de expressão [...]. Isso nos conduz ao tema dos direitos da personalidade e sua ponderação com os direitos ligados à liberdade de expressão". Cf. Rcl 22.328/RJ, $1^{\text {a }}$ Turma, DJe $19 / 04 / 2016$.

48 "A liberdade de expressão, a despeito de possuir uma posição preferencial nas democracias constitucionais contemporâneas, pode sofrer limitações, desde que razoáveis, proporcionais e que prestigiem, no caso concreto, outros direitos e garantias de mesmo status jusfundamental (grifo do autor)". Cf. RE 685.493, Plenário, DJe 22/05/2020.

49 A argumentação de Fux é confusa e de difícil compreensão, uma vez que o Ministro atribui ao direito à intimidade a mesma posição preferencial destinada à livre expressão. Ora, se ambos os direitos gozam desta posição de destaque, não há por que negar, por exemplo, as plausíveis reivindicações de preferência eventualmente feitas em nome de outros direitos fundamentais, como à vida e à saúde, ou, por fim, a própria utilidade do critério da posição preferencial para solucionar conflitos entre direitos situados no mesmo patamar de importância. Esse tipo de manifestação dificulta a formulação de distinções entre os dois testes para a solução de controvérsias sobre o tema. Para Fux na ADI 5122 (2018): "inexistem dúvidas de que o direito à intimidade compartilha da mesma preferred position ocupada pela liberdade de expressão, razão pela qual, em tese, pode limitá-la, sempre que a medida buscada supere o multimencionado teste de proporcionalidade".

50 Fux cita como exemplos: Palko v. Connecticut (1937) e United States v. CaroleneProductsCo. (1938) e Barroso (2004, p. 20) afirma que a doutrina surge na Suprema Corte, mas não cita nenhum julgado.

51 Idem, p. 489-490. Há duas razões adicionais que explicam o abandono da tese, igualmente, por juízes mais liberais da Suprema Corte: sua aplicação desmedida abriria espaço para a defesa de um libertarianismo na economia, além de repelir, de pronto, tentativas estatais de afetar problemas sociais redistributivos no campo comunicativo por meio das leis (KESSLER, 2016, p. 1915). 
Não fica claro, todavia, da análise dos votos dos ministros do STF, pois estes lançam mão de um teste abandonado pela Suprema Corte há, pelo menos, 60 anos. É bem verdade que eles sequer mencionam precedentes mais recentes de sua contraparte norte-americana ou trabalhos acadêmicos estrangeiros atuais que deem suporte ao teste, o que permite a inferência da formulação de uma interpretação original da Constituição de 1988, nada obstante inspirada numa vetusta doutrina estrangeira. De qualquer forma, para fins desta pesquisa, a posição preferencial da liberdade de expressão dos brasileiros e brasileiras assume um acento curioso, uma vez que a ela acopla-se a necessidade de balanceamento. Dessa forma, sugere-se que o teste passe a chamar-se, "posição preferencial relativa".

A posição preferencial relativa de Barroso e Fux sugere que a preponderância da liberdade de expressão dependerá do resultado de um indispensável processo de balanceamento prévio ao resultado, muito embora estruturado a partir da distribuição desigual do ônus argumentativo em favor daquela ${ }^{52}$. 0 processo interpretativo descrito, todavia, dificulta a distinção entre essa vertente do balanceamento de outra, supostamente, não qualificada e calcada na distinção estrutural alexyana entre normas cujo método proposto para a resolução de conflitos entre princípios, normas aplicáveis prima facie, é a proporcionalidade.

Alexy alega ser possível defender um conceito semântico de normas de direitos fundamentais possível de ser extraído de dispositivos constitucionais, desde que possam ser estruturados na forma de mandamentos de ônticos. Estruturalmente, portanto, é possível identificar regras como a espécie normativa que se caracteriza pela aplicabilidade irrestrita de sua consequência jurídica quando sua hipótese fática se observar. Por outro lado, os princípios são normas que se caracterizam por serem aplicáveis na maior medida do juridicamente e faticamente possível (mandamentos de otimização). As normas de direitos fundamentais principiológicas aplicam-se a partir de uma preferência prima facie. Assim, um princípio cederá lugar a outro quando, em determinado caso, em face das circunstâncias, for conferido a outro princípio antagônico um peso maior (ALEXY, 2008).

A tese da posição preferencial relativa lida pelo prisma da tese alexyana estabelece que a liberdade de expressão e o direito à honra, como normas principiológicas, não estariam na mesma posição no momento de eventual balanceamento, uma vez que a primeira já partiria para o processo decisório com alguns pesos (ônus argumentativos) de vantagem. Entretanto, na hipótese de serem apresentados pesos suficientes, capazes de fazer a balança pender em definitivo para o lado da honra, este seria o direito preponderante. Esse processo argumentativo demanda do intérprete a exposição clara do peso relativo da liberdade de expressão e qual limiar precisa ser ultrapassado pela honra para que tenha prevalência no caso concreto. Em síntese, o teste da posição preferencial relativa exige que o leitor saiba qual o valor dos pesos atribuídos a cada um dos direitos em conflito.

Não é possível, no momento e neste estudo, contestar a possibilidade de conciliarmos, no nível da teoria dos direitos fundamentais, a ideia de posição preferencial como um critério legítimo ou coerente para casos que envolvam a liberdade de expressão, entretanto, será inventariada uma série de questionamentos não respondidos pelos ministros e teóricos que a advogam:

1) Ainda que seja possível atribuir posição preferencial a um direito sem que isso caracterize a adoção de uma ordem lexical entre valores constitucionais (ponto impossível de ser desenvolvido aqui), é indiscutível que essa teoria inviabiliza a utilização de Robert Alexy como o teórico capaz de embasar esse tipo de balanceamento qualificado, uma vez que a premissa básica da proporcionalidade alexyana é a de que não existem relações de precedência condicionadas absolutas ou estipuladas no abstrato, circunstância particular que viabiliza o balanceamento entre princípios jurídicos ${ }^{53}$.

2) O balanceamento proposto por Alexy examina o conflito entre princípios a partir de critérios jurídicos (outros direitos) e fáticos para estabelecer as condições nas quais um deles terá precedência e, consequentemente, ditará as consequências jurídicas do caso. Não fica claro na tese da posição preferencial relativa o que caracteriza um "ônus argumentativo" no momento da análise dos critérios da proporcionalidade. Ou seja, não há evidências sobre quão "pesada" é a liberdade de expressão e como contrapor suas consequências jurídicas com argumentos jurídicos e fáticos contrários a elas.

52 Cf., voto de Barroso na Rcl 18.638 (2018): "A Carta de 88 incorporou um sistema de proteção reforçado às liberdades de expressão, informação e imprensa, reconhecendo uma prioridade prima facie destas liberdades públicas na colisão com outros interesses juridicamente tutelados, inclusive com os direitos da personalidade [...] embora não haja hierarquia entre direitos fundamentais, tais liberdades possuem uma posição preferencial, o que significa dizer que seu afastamento é excepcional e o ônus argumentativo é de quem sustenta o direito oposto".

53 Para reforçar o argumento, Virgílio Afonso da Silva (2011, p. 273-301) afirma o seguinte sobre a teoria de Alexy: "This means that there is no place for unconditional and absolute relations of precedence when it comes to weighing principles. The outcome of a balancing is always a conditional relation of precedence, because balancing is always case specific [..]) there is no absolute relation of precedence among principles". 
3) Não são oferecidas maiores razões para sustentar, no campo da teoria dos direitos fundamentais, a existência de um direito fundamental que goza de posição preferencial em face dos demais ${ }^{54} \mathrm{e}$ o que isso representa para a ideia de que todas as normas constitucionais possuem o mesmo valor jurídico (princípio da unidade da Constituição) ${ }^{55}$.

4) Por fim, será muito difícil, para voltar a um ponto anterior, diferenciar o emprego da proporcionalidade acrescida do teste da posição preferencial da sua aplicação não qualificada na prática jurisprudencial de uma Corte que não aplica nem a "tradicional" proporcionalidade de forma coerente, sistemática ou inteligível.

Morais, após colacionar 189 decisões do STF que utilizaram padrão decisório da proporcionalidade entre 20022012, concluiu que o tribunal não segue, rigorosamente, os subitens do teste proposto por Robert Alexy, dificultando a identificação do que seria a proporcionalidade para o STF (MORAIS, 2014, p. 54-62). Uma conclusão compartilhada por Lopes (2015, p. 78), que analisou a jurisprudência do STF no controle concentrado de constitucionalidade, e por Silva (2002). De acordo com Lopes, a proporcionalidade seria um enunciado performático - que acaba por encobrir as razões de decidir da Corte, pois nas ocasiões em que o tribunal a utiliza não fica claro qual o motivo pelo qual um princípio teria precedência sobre outro.

Ronaldo Macedo considera que o método padrão para o julgamento de casos relativos à liberdade de expressão no Brasil é a proporcionalidade, o qual é complementado por uma leitura pouco rigorosa da dignidade da pessoa humana e de uma justificativa casuística para a solução de casos. Os três elementos combinados dificultam a criação de uma teoria política sofisticada capaz de justificar esse direito no Brasil (MACEDO JUNIOR, 2017, p. 298). Esta confusão e fundamentação deficiente poderiam explicar a troca ou a natureza intermutável do princípio da proporcionalidade com o da razoabilidade na jurisprudência do STF, como defendeu anos antes Silva (2002, p. 31), e a possível convergência de resultado entre os ministros que empregam o teste da posição preferencial relativa e o da proporcionalidade não qualificada.

Contudo, não é possível ainda estabelecer uma correlação direta capaz de explicar quando os ministros irão divergir ou convergir em algum caso. Isso porque, independentemente do teste empregado, os ministros ainda assim apresentaram algumas posições convergentes. Barroso, ferrenho defensor do teste da posição preferencial, concordou com Gilmar Mendes, proeminente defensor do teste da proporcionalidade desde a ADPF 130, na recepção do crime de desacato pelo ordenamento constitucional. Em contrapartida, a ministra Rosa Weber, aplicando o teste da proporcionalidade, declarou o mesmo texto legal não recepcionado ${ }^{56}$.

\section{Considerações Finais}

O artigo pretendeu estudar a interpretação da liberdade de expressão desenvolvida pelo STF entre os anos de 2017 e 2020. Para tanto, focou em dois pontos interligados: o desenvolvimento das justificativas para a criação, manutenção e proteção do direito e os critérios ou testes empregados pela Corte para solucionar conflitos entre direitos fundamentais.

Inicialmente, ficou demonstrado o descompasso entre as justificativas desenvolvidas pela dogmática constitucional nacional, focadas na construção intrínseca da livre expressão e devedoras das teses clássicas do liberalismo, e as justificativas desenvolvidas pelo STF, caracterizadas pelo sincretismo incoerente de correntes filosóficas, mas que, ainda assim, realçavam o papel central desempenhado por este direito dentro do arranjo político instaurado com a transição democrática.

Tendo em vista que a Corte não explicitou a contento que tipo de arranjo democrático a liberdade de expressão brasileira deveria proteger, o artigo formulou a ideia de um regime democrático poliárquico, estruturado em volta da proteção de posições políticas capazes de viabilizar o exercício da oposição política. Dessa forma, em razão do processo de fusão simbiótica da democracia com um direito titularizado por cidadãos, foi possível considerar que o conteúdo relativo à livre expressão estava diretamente vinculado às manifestações que fossem avaliadas judicialmente como úteis à democracia brasileira. Não obstante a tese proposta, ainda é preciso que a academia especule sobre a função desempenhada pelas outras justificativas aventadas nos acórdãos e que formam o conteúdo periférico do direito.

54 Mesmo os teóricos que defendem uma possível conciliação entre direitos como trunfo e balanceamento, ou entre Alexy e Dworkin, não defenderiam que essa posição seria característica de apenas um direito, em detrimento dos demais (COSTA NETO, 2015).

55 Barroso (2019, p. 291) defende inexistir "hierarquia entre normas constitucionais", embora indique a existência de certa "hierarquia axiológica".

56 ADPF 496 (2020). 
A justificativa poliárquica, nos votos dos ministros, está assentada em uma leitura do processo de formação da sociedade e da política brasileiras, a demonstrar interpretações específicas que influenciam a decisão dos ministros, tais como: a existência de uma democracia racial no Brasil; fé na crença de que todas as religiões convivem entre si de forma harmoniosa; a necessidade, por parte da administração pública, de proteções reputacionais específicas, como, por exemplo, a necessidade de um campo de proteção e atuação diferenciados para o catolicismo.

Por outro lado, foi possível concluir que os ministros empregaram dois testes para solucionar conflitos que envolviam a liberdade de expressão, o da proporcionalidade e o da posição preferencial. Todavia, esses explicaram muito pouco sobre o significado de cada um dos testes, suas consequências jurídicas e como operavam na prática. O problema mais evidente foi equacionar o alcance do teste da posição preferencial, tendo em vista que os ministros o temperaram com a necessidade de fazer-se prévia ponderação entre direitos e com a ideia de que outros direitos também gozavam da mesma posição preferencial constitucional desfrutada pelo livre discurso. Por essa razão, o artigo considerou esse teste como uma produção original do STF e o renomeou como teste da "posição preferencial relativa".

\section{Referências}

AGRA, Walber de Moura. Curso de direito constitucional. 9. ed. Belo Horizonte: Fórum, 2018.

ALEXY, Robert. Teoria dos direitos fundamentais. São Paulo: Malheiros Editores, 2008.

BARROSO, Luis Roberto. Curso de direito constitucional contemporâneo: os conceitos fundamentais e a construção do novo modelo. 8. ed. São Paulo: Saraiva, 2019.

BARROSO, Luis Roberto. Colisão entre liberdade de expressão e direitos da personalidade. Critérios de ponderação. Interpretação constitucionalmente adequada do código civil e da lei de imprensa. Revista de Direito Administrativo, Rio de Janeiro, v. 235, p. 1-36, jan. 2004.

CARBONELL, Miguel. El fundamento de la libertad de expresión en la democracia constitucional. In: ORDOÑEZ, María Paz Ávila; SANTAMARÍA, Ramiro Ávila; GERMANO, Gustavo Gómez (org.). Libertad de Expresion: debates, alcances y nueva agenda. Quito: UNESCO, 2011. p 87-96.

CHEQUER, C. M. C. A liberdade de expressão como direito fundamental preferencial Prima Facie (análise crítica e proposta de revisão ao padrão jurisprudencial brasileiro). Rio de Janeiro: Lumen Juris, 2011.

COSTA NETO, João. Rights as trumps and balancing: reconciling the rreconcilable?. Rev. direito GV, São Paulo, v. 11, n. 1, p. 159-187, jun. 2015.

DA MATTA, Roberto. O que faz o brasil, Brasil? Rio de Janeiro: Rocco, 1986.

DAHL, Robert A. Polyarchy: participation and opposition. New Haven: Yale University Press, 1971.

DAHL, Robert A. Democracy and its critics. New Haven: Yale University Press, 1989.

DWORKIN, Ronald. $O$ direito da liberdade: a leitura moral da constituição norte-americana. São Paulo: Martins Fontes, 2006.

EPSTEIN, Lee; WALKER, Thomas G. Constitutional law for a changing america. 7. ed. Washington: Congressional Quartely Inc., 2010.

FAÚNDEZ LEDESMA, Héctor. Los límites de la libertad de expresión. México: UNAM, 2004.

FALLON JR, Richard H. The nature of constitutional rights. Cambridge: Cambridge University Press, 2019.

FAUSTO, Boris. História do Brasil. 13. ed. São Paulo: Editora da Universidade de São Paulo, 2010.

FERNANDES, Bernardo Gonçalves. Curso de direito constitucional. 6. ed. Salvador: Editora Juspodium, 2014.

FISS, Owen. Liberalism divided. Boulder: Westview Press, 1996. 
FISS, Owen M. Free speech and social structure. lowa Law Review, lowa, v. 71, n. 3, p. 1405-1425, 1986. FERRARI, Regina Maria Macedo Nery. Direito constitucional. São Paulo: Revista dos Tribunais, 2011.

FREYRE, Gilberto. Casa-grande \& senzala. 51. ed. São Paulo: Global, 2006.

HABERMAS, Jürgen. Between facts and norms: contributions to a discourse theory of law and democracy. Cambridge: The MIT Press, 1998.

HARTMANN, Ivar. Liberdade de expressão e capacidade comunicativa. Revista Brasileira de Direitos Fundamentais \& Justiça, Porto Alegre, v. 12, n. 39, p. 145-183, 2018.

HOLANDA, Sérgio Buarque. Raízes do Brasil. 27. ed. São Paulo: Companhia das Letras, 2014.

KESSLER, Jeremy K. The early years of first amendment lochnerism. Colum. L. Rev., New York, v. 116, n. 8, p. $1915-2004,2016$.

KOATZ, Rafael Lorenzo Fernandez. As liberdades de expressão e de imprensa na jurisprudência do Supremo Tribunal Federal. In: SARMENTO, Daniel (org.). Direitos fundamentais na jurisprudência do STF: balanço e crítica. Rio de Janeiro: Lumen Juris, 2011. p. 391-447.

LAURENTISS, Lucas Catib de; THOMAZINI, Fernanda Alonso. Liberdade de expressão: teorias, fundamentos e análise de casos. Revista Direito e Práxis, Rio de Janeiro, v. 11, n. 4, p. 2260-2301, 2020.

LEWIS, Anthony. Liberdade para as ideias que odiamos: uma biografia da Primeira Emenda à Constituição Americana. São Paulo: Acaraí, 2011.

LOPES, Karina Nathércia Sousa. Princípio da proporcionalidade: questionamentos sobre sua consistência e riscos do uso retórico do STF. 2015. Dissertação (Mestrado em Direito) - Programa de Pós-graduação em Direito, Universidade de Brasília, Brasília, 2015.

MACEDO JUNIOR, Ronaldo Porto. Freedom of expression: what lessons should we learn from US experience?. Revista Direito GV, São Paulo, v. 13, n. 1, p. 274-302, 2017.

MACHADO, Marta Rodriguez de Assis; LIMA, Márcia; NERIS, Natália. Racismo e insulto racial na sociedade brasileira: dinâmicas de reconhecimento e invisibilização a partir do direito. Novos estud. CEBRAP, São Paulo, v. 35, n. 3, p. 11-28, nov. 2016.

MARMOR, Andrei. Philosophy of law. Princeton: Princeton University Press, 2011.

MORGADO, Alice Furst. A tendência jurisprudencial do Supremo Tribunal Federal acerca da liberdade de expressão. 2011. Monografia (Aperfeiçoamento/Especialização em Escola de Formação) - Sociedade Brasileira de Direito Público, São Paulo, 2011.

MORAIS, F. S. Descobrindo o pressuposto hermenêutico do princípio da proporcionalidade. RECHTD - Revista de Estudos Constitucionais, Hermenêutica e Teoria do Direito, São Leopoldo, v. 6, n. 1, p. 54-62, 2014.

MELLO, Marco Aurélio Mendes de Farias. Liberdade de expressão. In: ROCHA, Fernando Luiz Ximenes; MORAES, Filomeno (coord.). Direito constitucional contemporâneo: estudos em homenagem ao professor Paulo Bonavides. Belo Horizonte: Del Rey, 2005. p. 595-606.

MENDES, Gilmar Ferreira; BRANCO, Paulo Gustavo Gonet. Curso de direito constitucional. 14. ed. São Paulo: Saraiva, 2019.

MITIDIERO, Daniel; SARLET, Ingo Wolfgang; MARINONI, Luiz Guilherme. Curso de direito constitucional. 4. ed. São Paulo: Revista dos Tribunais, 2015.

NOVELINO, Marcelo. Curso de direito constitucional. 11. ed. Salvador: JusPodivm, 2016.

RODRIGUEZ, J. R. Dogmática é conflito: a racionalidade jurídica entre sistema e problema. In: RODRIGUEZ, José Rodrigo; PÜSCHEL, Flávia Portella; MACHADO, Marta Rodriguez Assis (org.). Dogmática é conflito: uma visão crítica da racionalidade jurídica. São Paulo: Saraiva, 2012. p. 21-32. 
SANDEL, Michael. Democracy's discontent: america in search of a public philosophy. Cambridge: Belknap Press, 1998.

SARLET, Ingo Wolfgang. Liberdade de expressão e o problema da regulação do discurso do ódio nas mídias sociais. REI -Revista Estudos Institucionais, Rio de Janeiro, v. 5, n. 3, p. 1207-1233, dez. 2019.

SANKIEVICZ, Alexandre. Liberdade de expressão e pluralismo: perspectivas de regulação. São Paulo: Saraiva, 2011.

SANTOS, G. A. Nem crime, nem castigo: o racismo na percepção do judiciário e das vítimas de atos de discriminação. Revista do Instituto de Estudos Brasileiros, São Paulo, v. 1, n. 62, p. 184-207, 2015.

SANTOS, Carlos Victor Nascimento dos. O Supremo de "portas abertas": a colegialidade em ação. Direito, Estado e Sociedade, Rio de Janeiro, n. 56, p. 10-39, jan./jun. 2020.

SUNSTEIN, Cass. One case at time: judicial minimalism on the supreme court. Cambridge: Oxford University Press, 1999.

SILVA, Virgílio Afonso da. O proporcional e o razoável. Revista dos Tribunais, São Paulo, v. 798, ano 91, p. 23-50, abr. 2002.

SILVA, Virgílio Afonso. Interpretação constitucional e sincretismo metodológico. In: SILVA, Virgílio Afonso (org). Interpretação constitucional. São Paulo: Malheiros, 2005. p. 115-143.

SILVA, Virgílio Afonso da. Comparing the incommensurable: constitutional principles, balancing and rational decision. Oxford Journal of Legal Studies, Oxford, v. 31, n. 2, p. 273-301, 2011.

SICKAL, James $\mathrm{D}$. Legal tests to determine the constitutionality of statutes restricting first amendment freedoms. Missouri Law Review, Missouri, v. 26, n. 4, p. 471-500, 1961.

SWEET, Alec Stone; MATHEWS, Jud. Proportionality balancing and global constitutionalism. Columbia Journal of Transnational Law, Columbia, v. 47, p. 73-164, 2008.

TAVARES, André Ramos. Curso de direito constitucional. 17. ed. São Paulo: Saraiva, 2019.

TILLER, Emerson H.; CROSS, Frank B. What is legal doctrine?. Northwestern University Law Review, Chicago, v.100, n.1, p. 517-533, 2006.

TRIBE, Laurence H. Constitutional choices. Cambridge: Harvard University Press, 1985.

VALE, André Rufino do. A deliberação no Supremo Tribunal Federal: ensaio sobre alguns problemas e perspectivas de análise teórica. In: FELLET, Andre; NOVELINO, Marcelo (org.). Constitucionalismo e democracia. Salvador: Juspodivm, 2013. p. 329- 348.

VAN GEEL, Tyll. Understanding Supreme Court Opinions. 5. ed. New York: Pearson Longman, 2007. p. 81-93. VIANNA, Oliveira. Instituições políticas brasileiras. Rio de Janeiro: EDUFF, 1987.

VIEIRA, Oscar Vilhena. Direitos fundamentais: uma leitura da jurisprudência do STF. 2. ed. São Paulo: Malheiros, 2017.

WALDRON, Jeremy. The harm in hate speech. Cambridge: Harvard University, 2012.

WALDRON, Jeremy (ed.). Theories of rights. Oxford: Oxford University Press, 1984.

Recebido em: 19.02 .2021

Aceito em: 13.10 .2021 